\title{
Temporal Dynamic Modeling for the Assessment of Water Availability and its Effects on Sustainability of Water Resources at Boi Branco Sub-basin, SP, Brazil
}

\author{
By Alexandra Vaz Ferreira* \\ Rodrigo Máximo Sánchez-Román ${ }^{\dagger}$ \\ Alba María Guadalupe Orellana González.t.
}

\begin{abstract}
This study aimed at developing a Dynamic System (DS) Model to assess the sustainability of the use of water resources in the sub-basin of Boi Branco over a 10year time frame (2011-2021). Intensive irrigated agriculture occurs in the area, mostly using center-pivot irrigation. Simulations to determine the water supply, demand and sustainability index were performed under three scenarios involving: 1) $75 \%$ and $50 \%$ precipitation probability, and irrigation system efficiency, 2) 75\% and $50 \%$ precipitation probability, and environmental flow of 1/40 and 1/10 of the mean pluriannual flow, and 3) same rainfall pattern as observed between 1971 and 1980. Our results show that water demand is greater than potential surface water supply, reflecting vulnerabilities that allow classifying the condition of the sub-basin as critical, in accordance with Article 14 of Law 9034.
\end{abstract}

Keywords: Center Pivot Irrigation, Dynamic Systems, Simulation Models, Water Resources

\section{Introduction}

The adequate management of water resources is essential for the sustainable development, from both a quantitative and qualitative standpoint. Inefficient water use, pollution and degradation of water bodies are still major limiting factors for sustainability (Yoshikawa, 2014). Water plays an integrating role, and great losses follow when its quality and quantity are affected.

To ensure that water resources are used more efficiently, large-scale management and flexible water allocation systems are needed to meet the competing demands for water, not only for human use, energy production, agriculture, fishing and cities, but also for the keeping of healthy ecosystems such as forests, swamps and oceans (Banco Mundial, 2010; ONU, 2014; Nazemi and Wheater, 2015b).

The importance of water management is highlighted by the serious consequences that result when there is a lack of water (Schewe et al., 2014;

\footnotetext{
* Graduate Student, Sao Paulo State University (UNESP), Brazil.

${ }^{\dagger}$ Assistant Professor, Sao Paulo State University (UNESP), Brazil.

* Postdoctoral Fellow, Sao Paulo State University (UNESP), Brazil.
} 
Nazemi and Wheater, 2015a). Therefore, studies providing information and future trends in water use are very helpful in supporting decision making regarding water intervention policies and management (Goulart Jounior et al., 2011). Identifying decision-support tools is key to ensuring water sustainability and encouraging its rational use, as well as in promoting social responsibility.

The systems approach includes interdisciplinary studies capable of viewing reality from diverse and complementary angles. Moreover, it allows the consistent articulation of different methods and viewpoints using different sciences to draw conclusions and develop solutions to the problems identified.

The research purpose is the development of a dynamics systems (DS) model that can be applied to water resources, through the elaboration of an influence diagram of stocks and flows, the validation of the mathematical model representing the water supply and demand, comprehending in the Boi Branco sub-basin.

The simulation of the hydrologic system behavior under different scenarios, such as: a) the influence on water supply and the demand due to climate variability over the sub-basin; b) the influence of the irrigation systems efficiency in the volume of water available; c) to assess the importance and/or the influence of the environmental flow on water resources demand availability for irrigation.

\section{Materials and Methods}

This study was carried out in the sub-basin of the Boi Branco stream area, located in the Alto Paranapanema Water Resources Management Unit (UGRI 14) (Brasil, 2013). The Boi Branco sub-basin is located between the latitudes $23^{\circ} 36^{\prime} 01^{\prime \prime} \mathrm{S}$ and $23^{\circ} 29^{\prime} 00^{\prime \prime} \mathrm{S}$ and the longitudes $48^{\circ} 48^{\prime} 39^{\prime \prime} \mathrm{W}$ and $48^{\circ} 55^{\prime} 39^{\prime}$ ' $\mathrm{W}$. The right side watershed of the sub-basin lies southeast of the Paranapanema municipality, while the left side watershed is situated southeast of the Itaí municipality, state of São Paulo, Brazil. Intensive irrigated agriculture $\left(20.09 \mathrm{~km}^{2}\right)$, mostly using center-pivot irrigation, occurs in the area that is cultivated with wheat, cotton, corn, beans, potatoes and soybeans through out the year. 
Figure 1. Boi Branco Sub-basin Located between the Municipalities of Itai and Paranapanema and its Delimited Sub-basin Area. Image on the Right (Apple Maps, 2013) processed by the authors.

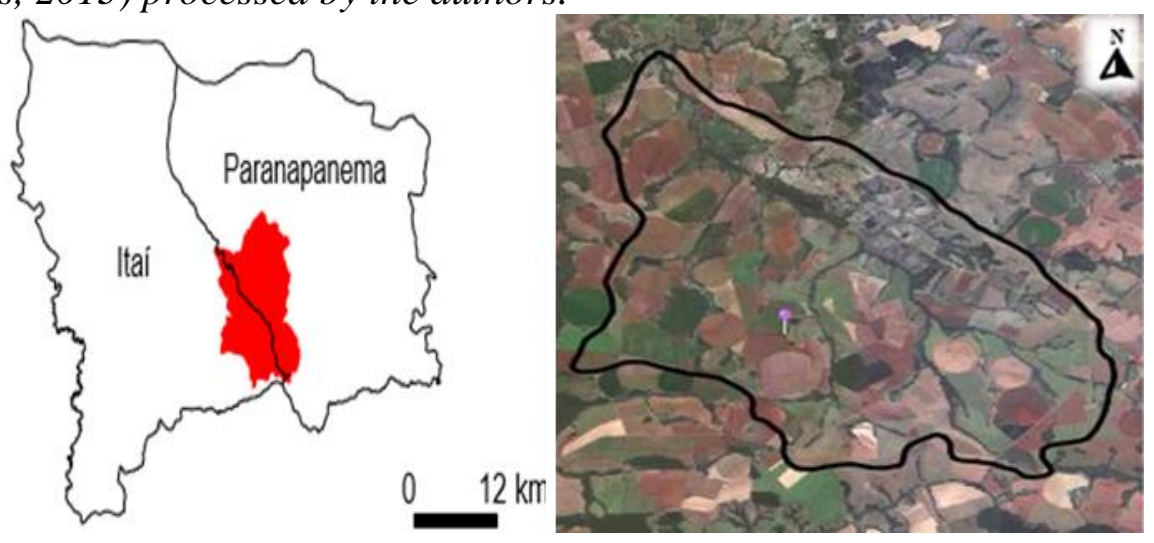

According to the Department of Water and Electric Power (DAEE), the condition of the Boi Branco sub-basin is critical in terms of water availability as the permitted flow rate exceeds $50 \%$ of the reference streamflow $\left(Q_{7}^{10}\right)$. Therefore, in accordance with the State Law 9034 of December 27, 1994 (CBH-ALPA, 2012), this body of water requires special management procedures (LEI 9034, 1994).

In order to assess the water resources sustainability in the Boi Branco subbasin, a water resources model (BB-WRM) was developed using System Dynamics (SD) to simulate the structure of water demand in the rural community, agriculture, and environment (for supporting local ecosystems), and the available water supply in the area (Schewe et al., 2014; Nazemi and Wheater, 2015a; 2015b).

The BB-WRM model was developed using STELLA software, version 9.1.3 for Windows (ISEE SISTEMS, 2012). The model represents the most important relations to the study of the sub-basin structure of the Boi Branco stream analysing the balance between the amount of water available and required.

The water supply is built by the surface waters of the Boi Branco subbasin, its affluents and by the underground waters, whereas the hydric demand of the model represents the water consumption by the agricultural sector, the rural population and the environmental demand.

The Boi Branco sub-basin Water Resources Model (BB-WRM) was constructed following the three-step process for SD model building outlined by Orellana-González (2006), as follows: i) Conceptualization; ii) Formulation, and iii) Model assessment and exploitation.

\section{i) Conceptualization Stage}

During the conceptualization stage, a causal diagram was developed, as proposed by Sánchez-Román et al. (2009), to portray the relationships that are key to the study of the structure of water demand and supply in the Boi Branco sub-basin. The diagram shows the major structural components of the water 
resources model used to assess the balance between available water and water demand.

ii) Formulation Stage

The formulation stage consisted in drawing a stock and flow diagram describing in further detail the Boi Branco sub-basin structure (Figure 2), on which the development of model equations was based.

Figure 2. BB-WRM Stock and Flow Diagram

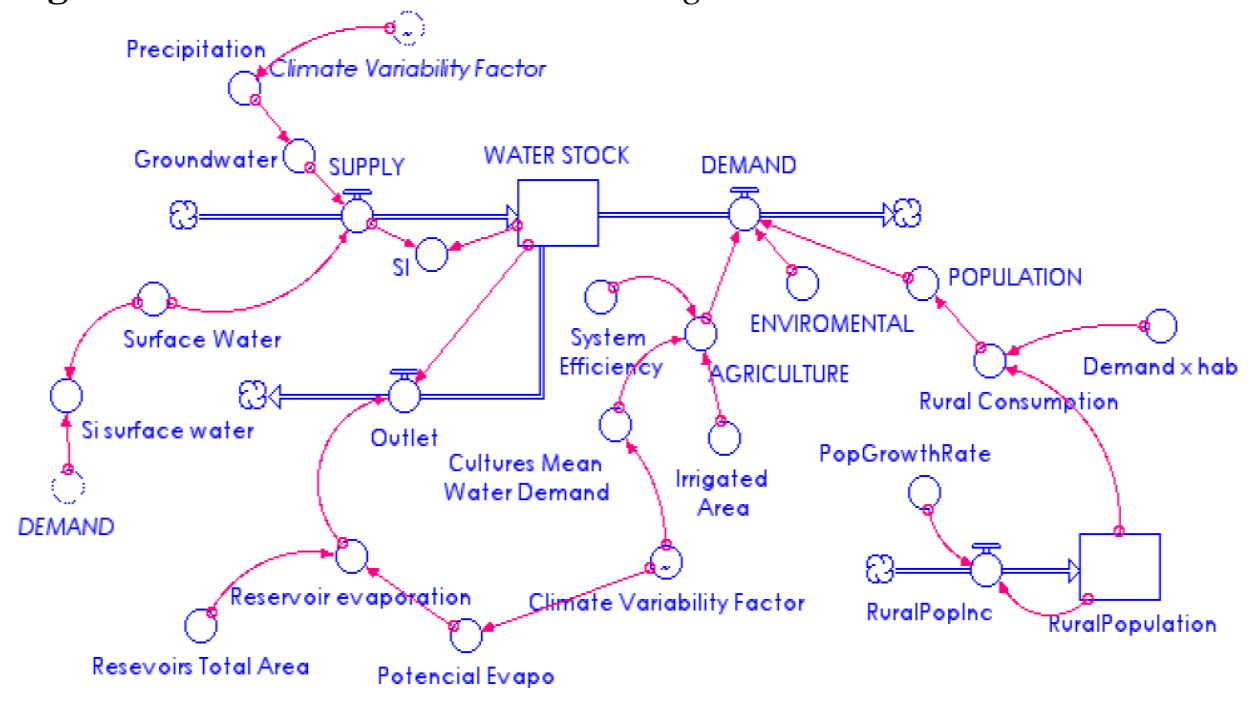

iii) Assessment and Exploitation Stage

This stage is of utmost importance because the purpose of a study based on SD principles provides a basis for evaluating different strategies and policies to improve a system's performance. SD model calibration is required to detect potential flaws in model construction. Otherwise, the results obtained during simulation may greatly differ from reality, making its use as an assessment tool questionable.

In this study, model validation was accomplished by comparing BB-WRM (BB-WRM: Boi Branco Water Resources Model; MRH-BB: Modelo de Recursos Hídricos - Boi Branco) simulation results for population growth with those obtained through the Excel software (Figure 3). 
Figure 3. Results regarding Population Growth between 2011 and 2021 in the Boi Branco Sub-basin Area Obtained by BB-WRM Simulation and through Excel Calculation

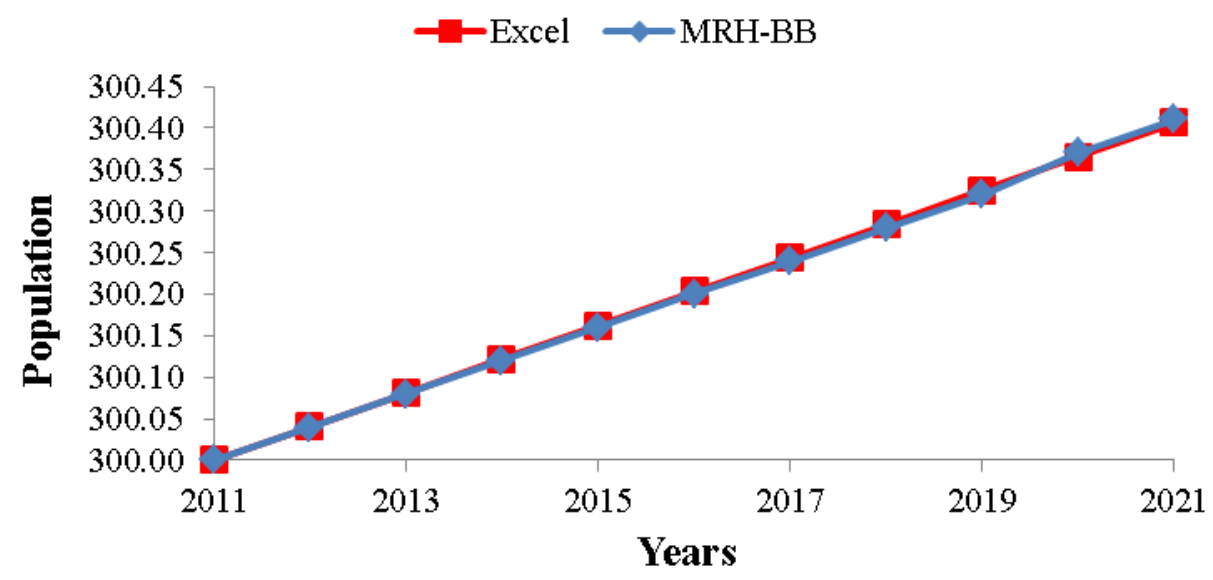

Analysis of the Results

The results were analyzed using the Sustainability Index (SI), proposed by $\mathrm{Xu}$ et al. (2002) and is defined as the ratio of possible water deficit relative to the corresponding supply in the same area.

IS $=\frac{\text { Available water }}{\text { Supply }}$

SI values greater than 0.2 reflect low or no water supply stress, implying that water demand is lower than or equal to $80 \%$ of the potential water supply. In contrast, SI values lower than 0.2 indicate vulnerable conditions, suggesting that the water demand is greater than $80 \%$ of the potential water supply. SI values of zero show that water demand is equal to or exceeds all available local water resources, and that water supply is therefore unsustainable (Xu et al., 2002; Orellana-González, 2006).

\section{Data Sources}

Water demand by all the different sectors was defined based on information collected in situ. Since knowledge of the characteristics of water use in the study area is vital for the effective modeling of irrigated agriculture, the data collected included irrigated area size, mean annual agricultural water use, water availability, water precipitation in the sub-basin area, and mean pluriannual flow.

Three model scenarios were run over a 10-year time frame (from 2011 to 2021). 
For the analysis of surface water resources, mean pluriannual flow was considered to be $0.551 \mathrm{~m}^{3} \mathrm{~s}^{-1}$, as reported on the DAEE website ${ }^{1}$. Groundwater availability was estimated assuming that $10 \%$ of the total annual precipitation infiltrates into the ground and percolates to the water table (Reichardt, 1978).

The impact of water use on the Boi Branco sub-basin was assessed, in the first scenario, using indexes that relate water availability, water used by different sectors, $75 \%$ and $50 \%$ probability of precipitation, potential evapotranspiration in the area, and irrigation system efficiency of $70 \%, 75 \%$, $80 \%, 85 \%$ and $90 \%$, according to Mendonza and Frizzone (2012).

In the second scenario, the environmental flow was considered to be $434.408 \mathrm{~m}^{3}$ year $^{-1}$ (1/40 of the mean pluriannual flow) and $1,737,633 \mathrm{~m}^{3}$ year $^{-1}$ (1/10 of the mean pluriannual flow) (Souchon and Keith, 2001).

In the third scenario, the annual precipitation pattern between 2011 and 2021 was simulated considering it as being the same as that observed between 1971 and 1980. Environmental flow was assumed to be constant at $434,408 \mathrm{~m}^{3}$ $\operatorname{year}^{-1}$ (1/40 of the mean pluriannual flow), and the irrigation system efficiency to be $90 \%$ (Table 1 ).

Table 1. Stock and Flow Diagram- Input Data

\begin{tabular}{|c|c|}
\hline Variables used & Values \\
\hline Irrigated area & $20.09 \mathrm{~km}^{2}$ \\
\hline Mean annual agricultural water use & $525 \mathrm{~mm}$ \\
\hline Mean pluriannual flow & $0.551 \mathrm{~m}^{3} \mathrm{~s}^{-1}$ \\
\hline Mean annual precipitation & $13,299.2 \mathrm{~m}^{3} \mathrm{ha}^{-1}$ \\
\hline $\begin{array}{l}\text { Mean annual potential } \\
\text { evapotranspiration }\end{array}$ & $1,070.4 \mathrm{~mm}$ \\
\hline Rural population & 300 people \\
\hline Annual population growth rate & $0.01353 \%$ \\
\hline Irrigation system efficiency & $70 \%, 75 \%, 80 \%, 85 \%$ e $90 \%$ \\
\hline Environmental flow & $\begin{array}{l}1 / 40 \text { and } 1 / 10 \text { of mean pluriannual } \\
\text { flow }\end{array}$ \\
\hline Precipitation probability to occur & $75 \%$ and $50 \%$ \\
\hline Groundwater recharge & $10 \%$ of precipitation \\
\hline
\end{tabular}

\section{Results and Discussion}

In order to assess the sustainability of the water resources in the Boi Branco sub-basin, 15 simulations of the influences and restrictions affecting

\footnotetext{
${ }^{1}$ http://www.sigrh.sp.gov.br/cgi-bin/regnet.exe/calcgeo\#r
} 
water demand and water supply in the area were performed as shown in Table 2.

Table 2. Scenarios Developed for the Assessment of Boi Branco Sub-basin

\begin{tabular}{ll}
\hline Scenarios & Simulations \\
\hline & Effect of $75 \%$ (i) and $50 \%$ (ii) precipitation probability with \\
& irrigation system efficiency at (a) $70 \%,(\mathrm{~b}) 75 \%,(\mathrm{c}) 80 \%,(\mathrm{~d}) 85 \%$, \\
& and (e) $90 \%$ of Boi Branco sub-basin water resources availability \\
& and sustainability index between 2011 and 2021. \\
\hline & Effect of $75 \%$ (i) and $50 \%$ (ii) precipitation probability, and \\
& environmental flow of (f) $1 / 40$ and (g) $1 / 10$ of the perennial flow of \\
& water resources availability and sustainability index in the Boi \\
& Branco sub-basin between 2011 and 2021. \\
\hline 3 & Water resources behavior and sustainability index considering the \\
& annual precipitation pattern between 2011 and 2021 as being the \\
& same as that observed between 1971 and 1980. \\
\hline
\end{tabular}

Scenario 1: Effect of 75\% (i) and 50\% (ii) Precipitation Probability with Irrigation System Efficiency at (a) 70\%, (b) 75\%, (c) 80\%, (d) 85\%, and (e) 90\% on Water Resources Availability and Sustainability Index in the Boi Branco Sub-basin between 2011 and 2021

Scenario 1 includes the climate variability factor to be taken into account when designing irrigation projects. A probability level of $75 \%$ indicates the minimum amount of rain precipitation likely to occur, i.e., the minimum amount of precipitation expected to occur in three out of four years. A 50\% probability represents the minimum precipitation expected in two out of four years. Both $75 \%$ and $50 \%$ precipitation probability levels were simulated with irrigation system efficiency at $70 \%, 75 \%, 80 \%, 85 \%$ and $90 \%$, in accordance to Bernardo et al. (2006), and Mendonza and Frizzone (2012), who consider an irrigation efficiency of $80 \%$ to be adequate for central pivot irrigation. Scenario 1 simulation results are shown in Figure 4.

Figure 4. Total Water Demand at $75 \%$ and $50 \%$ Precipitation Probability Levels as a Function of Irrigation Efficiency

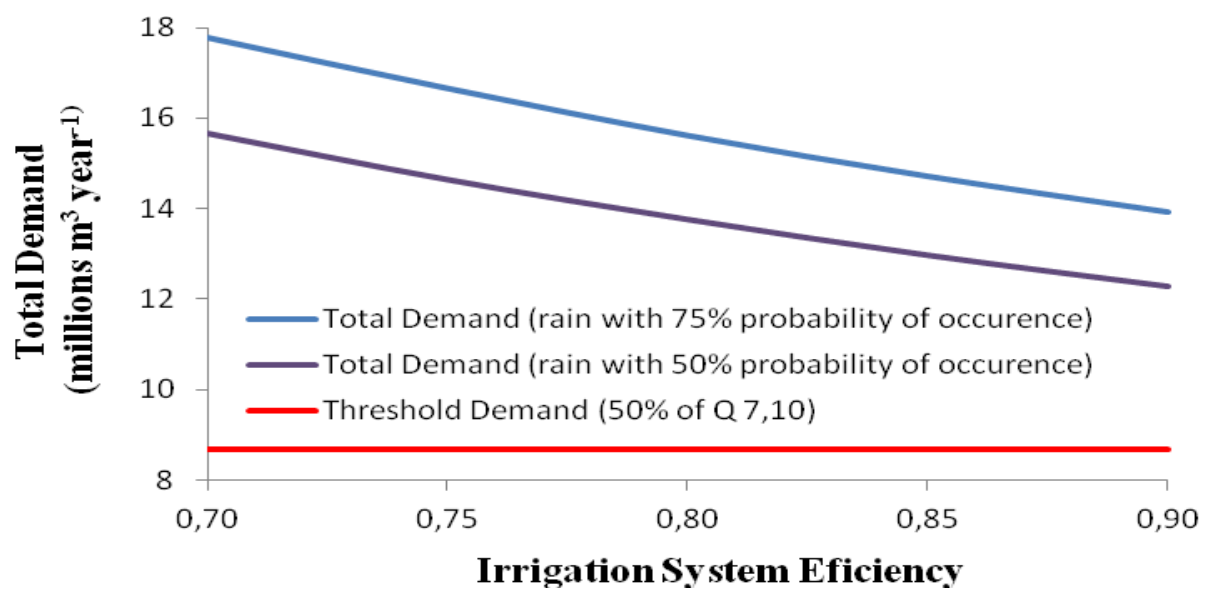


The rainfall expected to occur at $75 \%$ and $50 \%$ precipitation probability levels amounts to 26.71 million $\mathrm{m}^{3}$ year ${ }^{-1}$ and 28 million $\mathrm{m}^{3}$ year ${ }^{-1}$, respectively. Figure 4 shows that water demand at $50 \%$ precipitation probability is lower than that at $75 \%$ probability, which provides the least favorable climate condition to crop areas since it requires the enhancement of water supply through irrigation.

Figure 4 also shows that water demand decreases as irrigation efficiency increases, implying that good practices in the management of irrigation systems can diminish water consumption.

According to Article 4 of state Law 9.034 of December 27, 1994, the Boi Branco sub-basin is considered to be in a critical condition because consumption in the area exceeds $50 \%$ of the reference streamflow. This indicates that the use of water from this source is unsustainable (Figure 5).

Figure 5. Agricultural Water Demand at $75 \%$ and $50 \%$ Precipitation Probability Levels and as a Function of Irrigation Efficiency

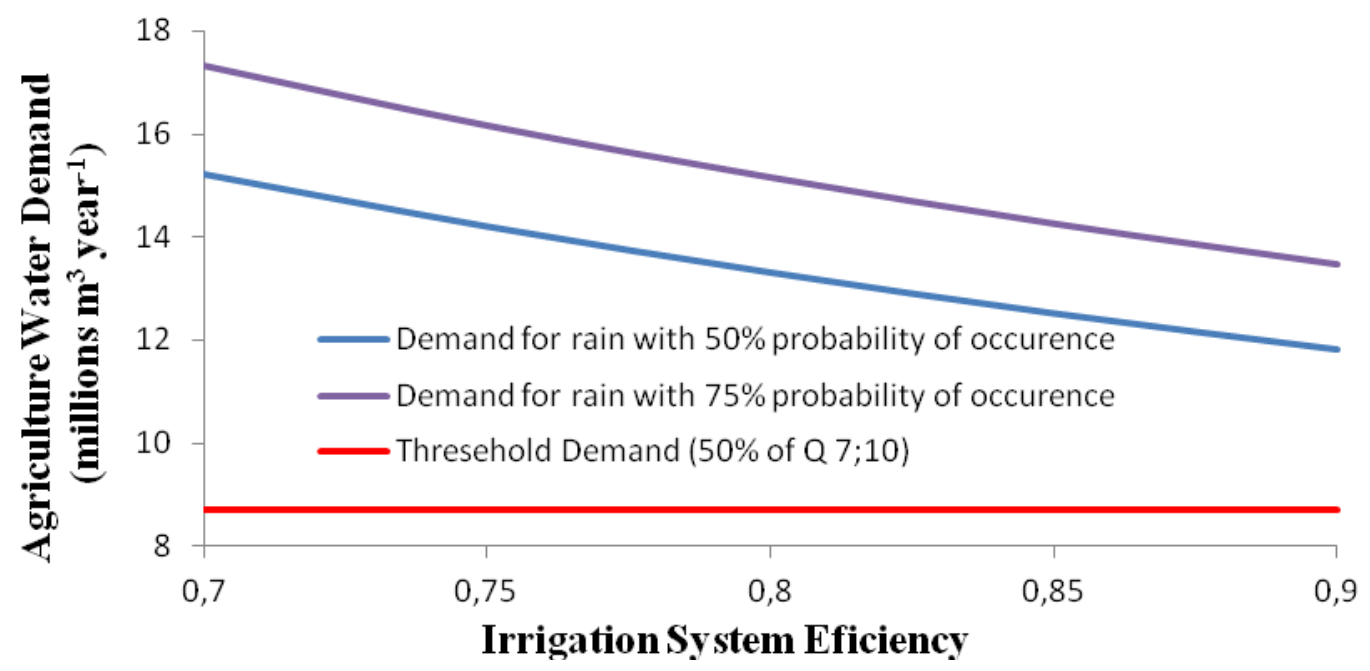

Figures 4 and 5 allow us to observe that the agricultural water demand and the total demand were quite similar, with population and environmental demands being thus negligible. This confirms the information that agricultural water consumption predominates in the study area.

Figures 6 and 7 show Sustainability Index performance. It is noteworthy that, as previously defined in this study, SI values greater than 0.2 indicate low or no water supply stress. 
Figure 6. Overall Sustainability Index Projected for the Period between 2011 and 2021

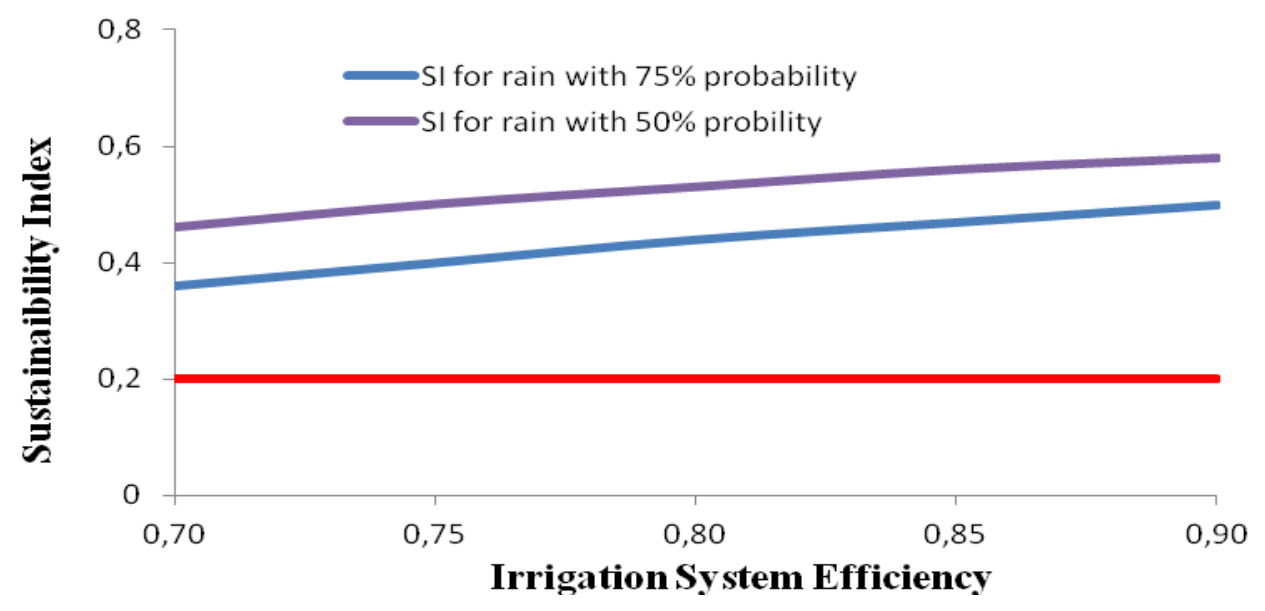

Simulations of both $75 \%$ and $50 \%$ precipitation probability levels with all the irrigation efficiency values investigated in this study showed that the overall SI is higher at $50 \%$ than at $75 \%$ precipitation probability, and is greater than the reference value at both levels. This indicates that the sub-basin water volume is enough to meet the demand of agriculture, which is then sustainable, posing no risk to the Boi Branco sub-basin water resource.

SI values ranging from 0.38 to 0.43 at $75 \%$ precipitation probability, and from 0.46 to 0.58 at $50 \%$ probability indicate that $57 \%$ and $42 \%$, respectively, of the water available in the Boi Branco sub-basin is used, implying that the exploitation of this water resource is sustainable. It is worth of note, however, that the overall SI was calculated based on the BB-WRM total water supply that corresponds to the sum of surface water with groundwater. Given that, in the sub-basin area, nearly all water withdrawals come from surface water, the picture shown in Figure 7 is the most compatible with reality.

Figure 7. Surface Water Sustainability Index for the Period between 2011 and 2021

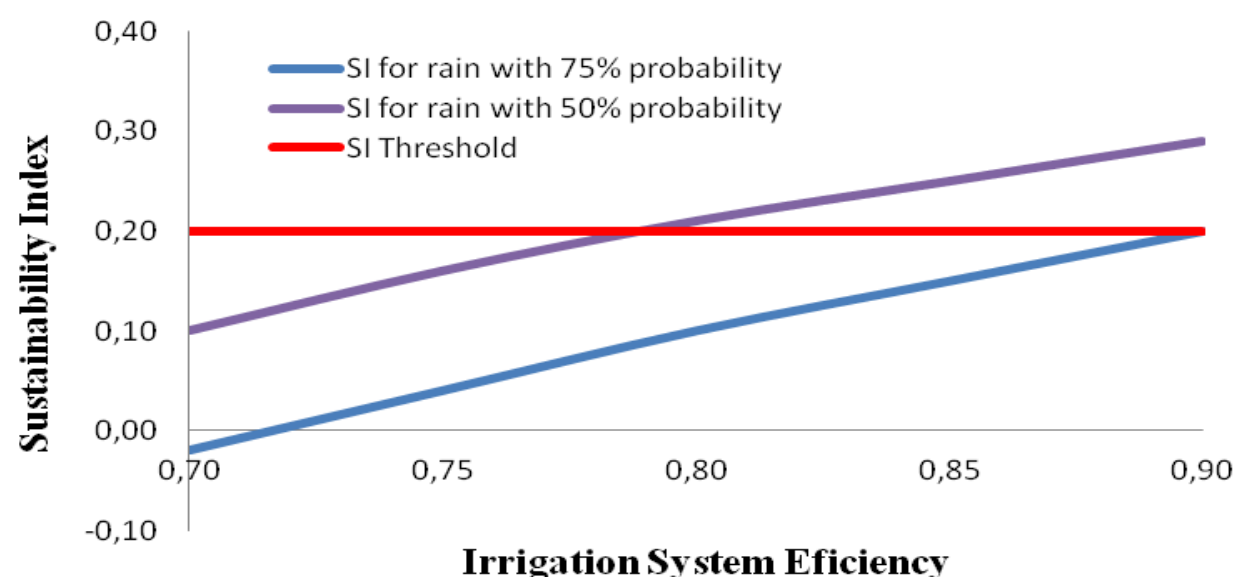


The analysis of SI considering surface water volume alone (17.38 million $\mathrm{m}^{3}$ year ${ }^{-1}$ ) suggests that this scenario is unsustainable. With $75 \%$ precipitation probability, irrigation efficiency is ineffective because SI remains below the 0.2 limit, regardless of the irrigation system used. This indicates that the surface water resource is in a vulnerable condition as water demand is likely to be higher than $80 \%$ of the potential water supply. At a precipitation probability of $50 \%$, in turn, agriculture cannot be sustainable unless irrigation efficiency equals or exceeds $80 \%$. Otherwise, irrigated agriculture in the Boi Branco subbasin area is totally unsustainable under adverse climate conditions.

Irrespective of climate factors, sustainability in the Boi Branco sub-basin is possible only if groundwater is used together with surface water for irrigation.

Scenario 2: Effect of precipitation probability at (i) $75 \%$ and (ii) $50 \%$, and environmental Flow of $(f) 1 / 40$ and $(g$ ) 1/10 of the Pluriannual Flow on Water Resources Availability and Sustainability Index in the Boi Branco Sub-basin between 2011 and 2021

In this scenario, simulations were done with precipitation probability levels at $75 \%$ and $50 \%$ in addition to environmental flow parameters, according to Souchon and Keith (2001). To this end, environmental flow was assumed to be $434,408 \mathrm{~m}^{3}$ year ${ }^{-1}$ (1/40 of mean pluriannual flow), and $1,737,633 \mathrm{~m}^{3}$ year $^{-1}$ (1/10 of mean pluriannual flow). Irrigation efficiency was considered to be $90 \%$ in all simulations. The results of the Scenario 2 simulation for total water demand are shown in Figure 8.

Figure 8. Total Water Demand with Precipitation Probability Levels at $75 \%$ and $50 \%$ as a Function of Environmental Flow Corresponding to 1/40 and 1/10 of Mean Pluriannual Flow

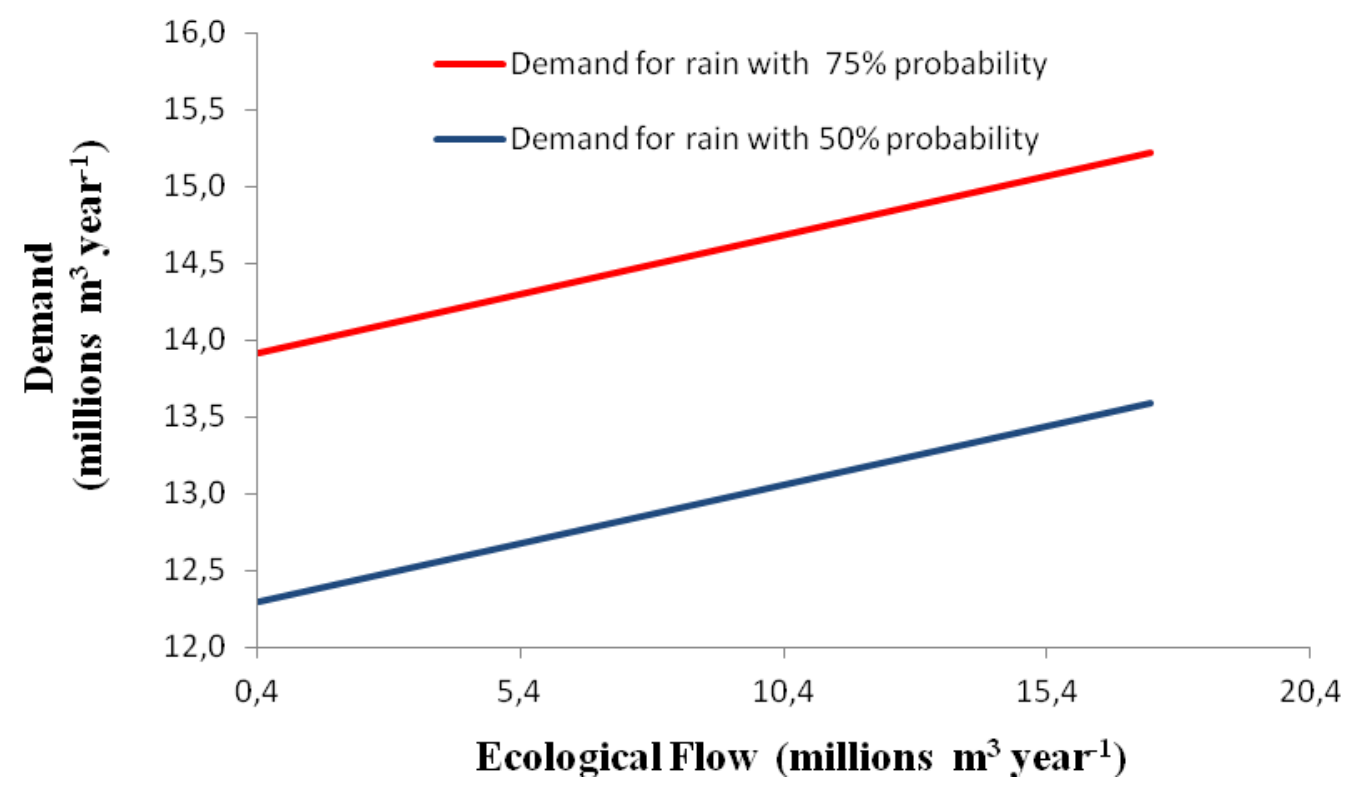


Under this scenario, water supply amounts to about 26.7 million $\mathrm{m}^{3}$ year $^{-1}$ and means demand to approximately 14.5 million $\mathrm{m}^{3}$ year ${ }^{-1}$ and 12,9 million $\mathrm{m}^{3}$ year $^{-1}$ for precipitation probability at $75 \%$ and $50 \%$, respectively, for the 2011-2021 period. Figure 8 shows that the total demand is lower with precipitation probability at $50 \%$ than at $75 \%$. An explanation for this is that the greater precipitation volume ensures water supply to the crops, mitigating the need for irrigation in the area. Regarding the influence of the environmental flow on the demand, it is possible to observe that with a $75 \%$ precipitation probability, water demand are about 15.228 million $\mathrm{m}^{3}$ year $^{-1}$ and 13.925 million $\mathrm{m}^{3}$ year ${ }^{-1}$ whereas with a $50 \%$ precipitation probability, it is about 13.595 million $\mathrm{m}^{3}$ year ${ }^{-1}$ and 12.292 million $\mathrm{m}^{3}$ year $^{-1}$ when flow is $1 / 10$ and 1/40, respectively. Water demand by agriculture can be seen in Figure 9.

Figure 9. Agricultural Water Demand with Precipitation Probability Levels at 75\% and 50\% as a Function of Environmental Flow Corresponding to 1/40 and 1/10 of Mean Pluriannual Flow

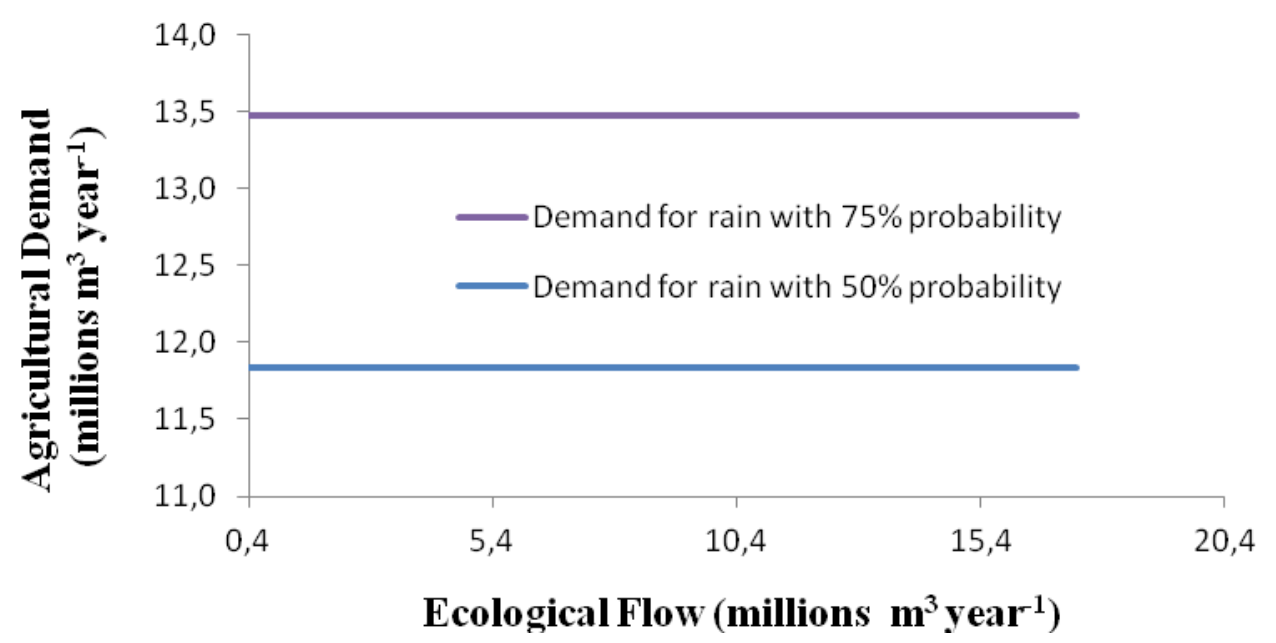

Figure 9 demonstrates that agricultural water demand, similarly to total water demand, remains unchanged at both levels of precipitation probability. However, water demand at a $50 \%$ probability $\left(11.839\right.$ million $\mathrm{m}^{3}$ year $\left.^{-1}\right)$ is lower than that observed at a $75 \%$ level $\left(13.472\right.$ million $\mathrm{m}^{3}$ year $\left.^{-1}\right)$. Furthermore, Figure 9 shows that environmental flow also has no influence on agricultural water demand.

Simulations of both $75 \%$ and $50 \%$ precipitation probability levels, as well as of both values of environmental flow demand investigated in this study, showed that the overall SI is higher at $50 \%$ than at $75 \%$ precipitation probability, and is greater than 0.2 at both levels. This indicates that the subbasin water volume is enough to meet the demand of agriculture, which is then sustainable and poses no risk to the Boi Branco sub-basin (Figure 10). 
Vol. 3, No. 2 Ferreira et al.: Temporal Dynamic Modeling for the Assessment of ...

Figure 10. Global SI with Environmental Flow of $1 / 40$ and $1 / 10$ for the Period between 2011 and 2021

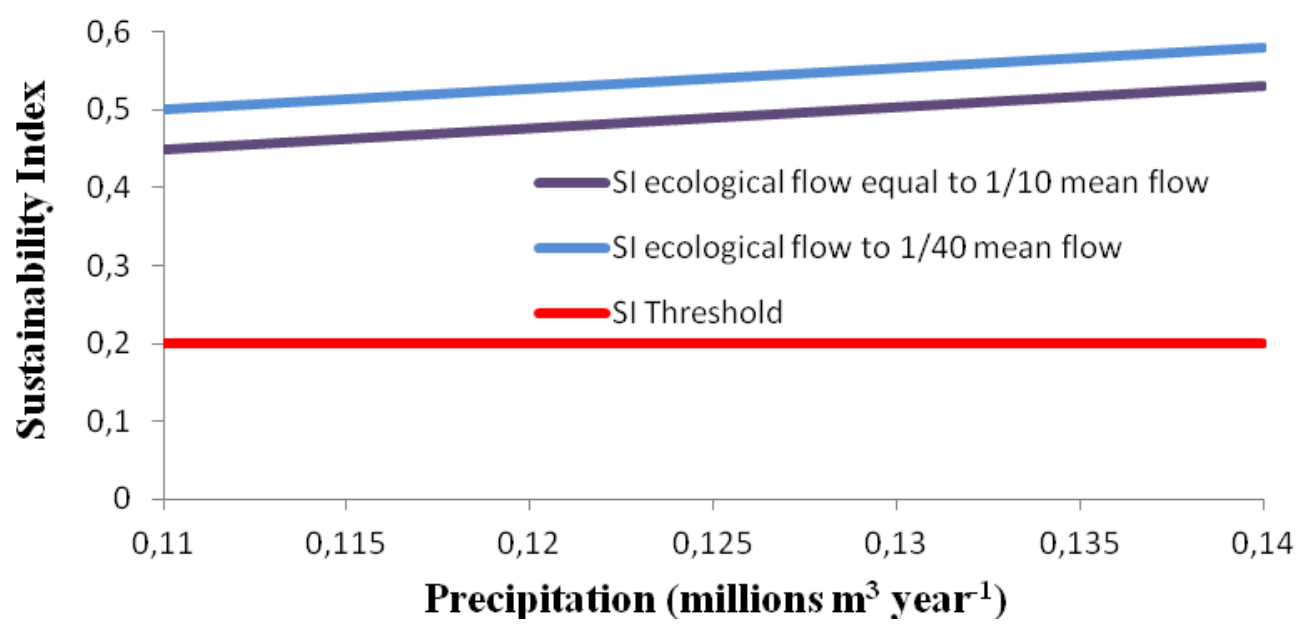

SI values ranging from 0.50 to 0.58 , and from 0.45 to 0.53 with environmental flows of $1 / 40$ and $1 / 10$ of the mean pluriannual flow, indicate that $46 \%$ and $51 \%$, respectively, of the water available in the Boi Branco subbasin is used. This indicates low or no water stress. The result related to surface water SI, which corresponds to the actual conditions found at the Boi Branco sub-basin area, is shown in Figure 11.

Figure 11. Projected Surface Water SI for the Period between 2011 and 2021 with Environmental Flow Corresponding to $1 / 40$ and 1/10

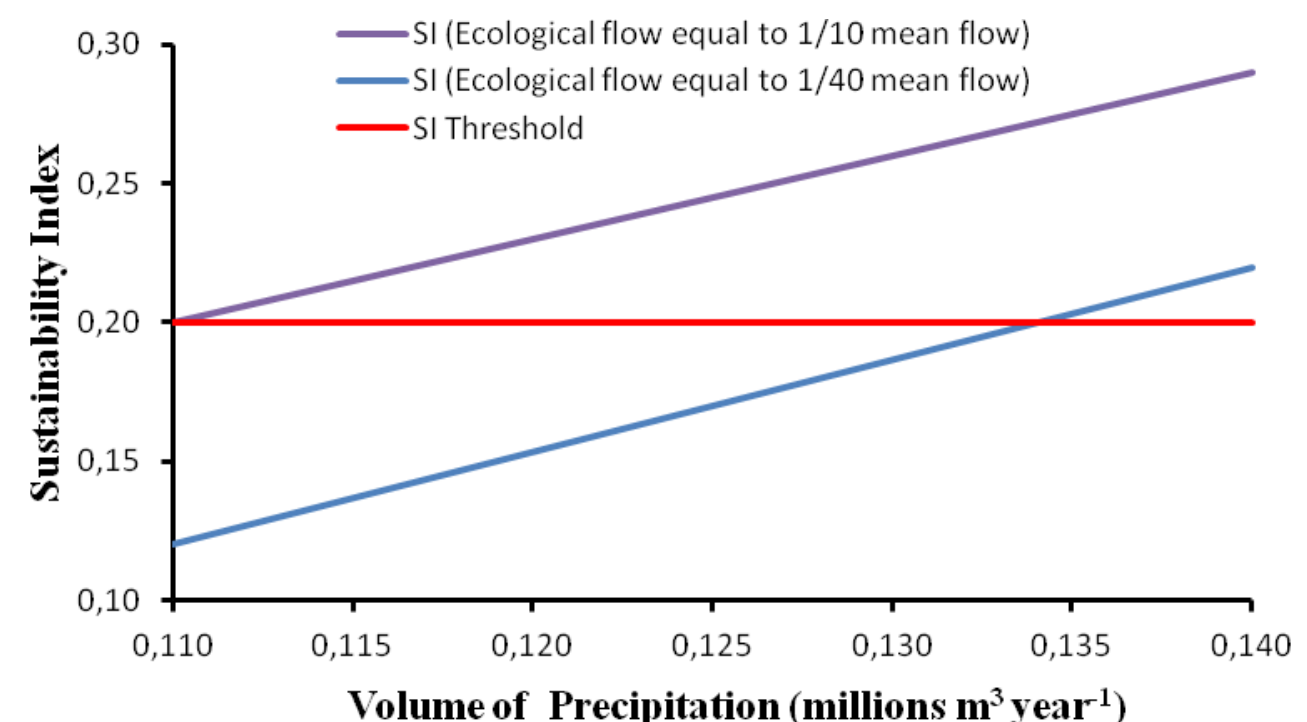

The analysis of SI as a function of surface water volume alone (17.3 million $\mathrm{m}^{3}$ year ${ }^{-1}$ ) shows that this scenario is unsustainable. With the environmental flow corresponding to $1 / 40$ of the mean pluriannual flow, the 
value of SI is initially equal to 0.2 , but remains above this limit later on. This indicates that agricultural activities are totally sustainable with very low stress on water supply. In contrast, the use of an environmental flow corresponding to $1 / 10$ of the mean pluriannual flow allows us to observe that the water resource is vulnerable and is being exploited in an unsustainable manner. SI remained below 0.2 almost throughout all the simulation process, suggesting that the demand exceeds $80 \%$ of the water supply.

Thus, SI with environmental flow corresponding to $1 / 40$ of the mean pluriannual flow is superior under both climate scenarios, and might provide a basis for management considering water multiple uses, as it represents an adequate quantitative guarantee and thus contributes to sustainability in the sub-basin area.

In the analysis of precipitation probability associated with environmental flow demand, the best results found were those obtained using precipitation probability at $50 \%\left(0.13\right.$ million $\mathrm{m}^{3}$ year $\left.{ }^{-1}\right)$ with the environmental flow demand being $1 / 40$ of the mean pluriannual flow. This clearly shows the importance of the environmental flow in the management of water resources.

Scenario 3: Water Resource Behavior and Sustainability Index Considering the Annual Precipitation Pattern between 2011 and 2021 as Being the Same as that Observed from 1971 and 1980

In the third and last scenario, annual precipitation pattern were simulated based on a 10-year rainfall data (from 1971 to 1980). Environmental flow was considered to be $434,408 \mathrm{~m}^{3}$ year $^{-1}$ (1/40 of the pluriannual mean), and the irrigation system as $90 \%$. Figure 12 shows the result of scenario 3 simulation for water supply and total demand.

Figure 12. Total Water Supply and Total Demand

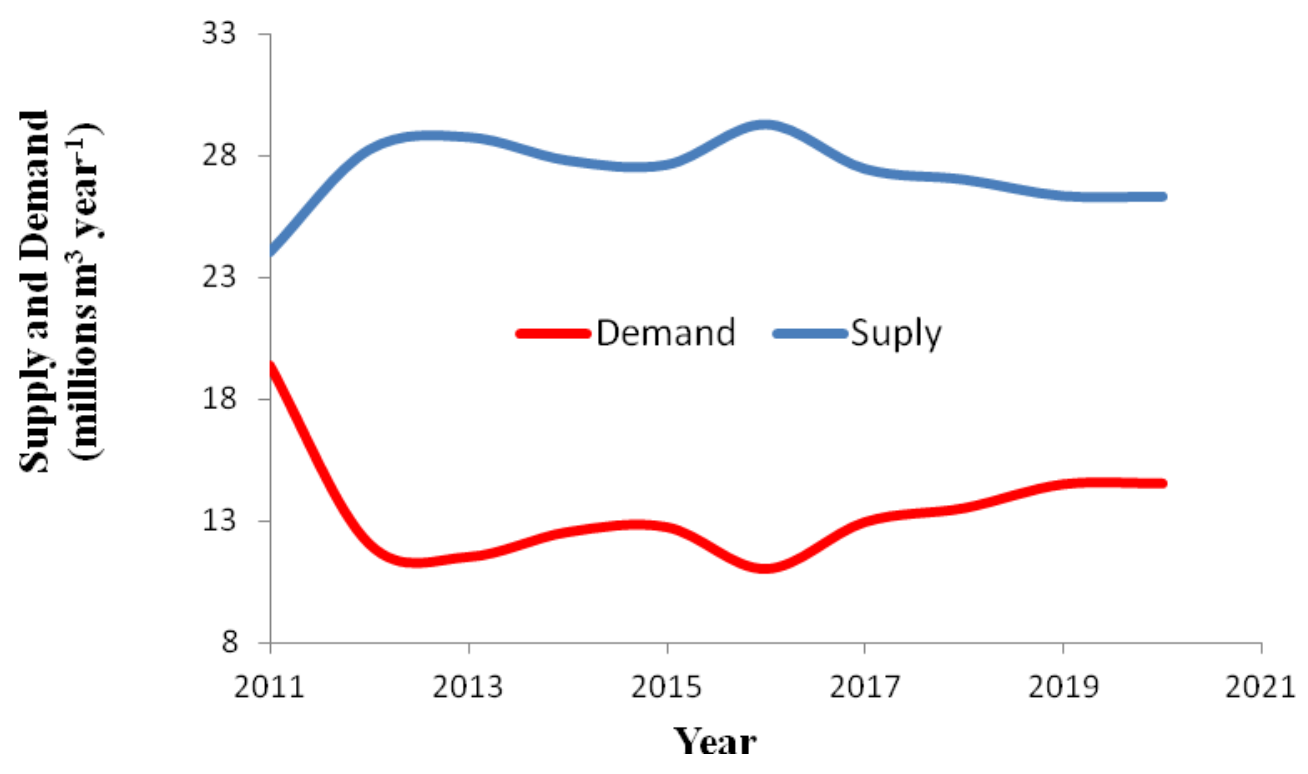


Under this scenario, the maximum water demand is about 20 million $\mathrm{m}^{3}$ year ${ }^{-1}$ in the year 2011, and the minimum of 11 million $^{3}$ year $^{-1}$ in 2016.

Throughout the period under study, water demand remained below supply, indicating that the water resources in the Boi Branco sub-basin are sufficient to support irrigation. In this case, the sub-basin condition could not be classified as critical by DAEE because it does not fall under Article 14 of Law 9.034.

Nonetheless, comparing the supply from surface water with the demand (Figure 13) shows that the demand in 2011 is 19.5 million $^{3}$ year ${ }^{-1}$ while the supply amounts to approximately 17.5 million $\mathrm{m}^{3}$ year $^{-1}$, i.e., the demand is 2 million de $\mathrm{m}^{3}$ year $^{-1}(1.11 \%)$ greater than the supply.

Figure 13. Surface Water Supply and Total Demand

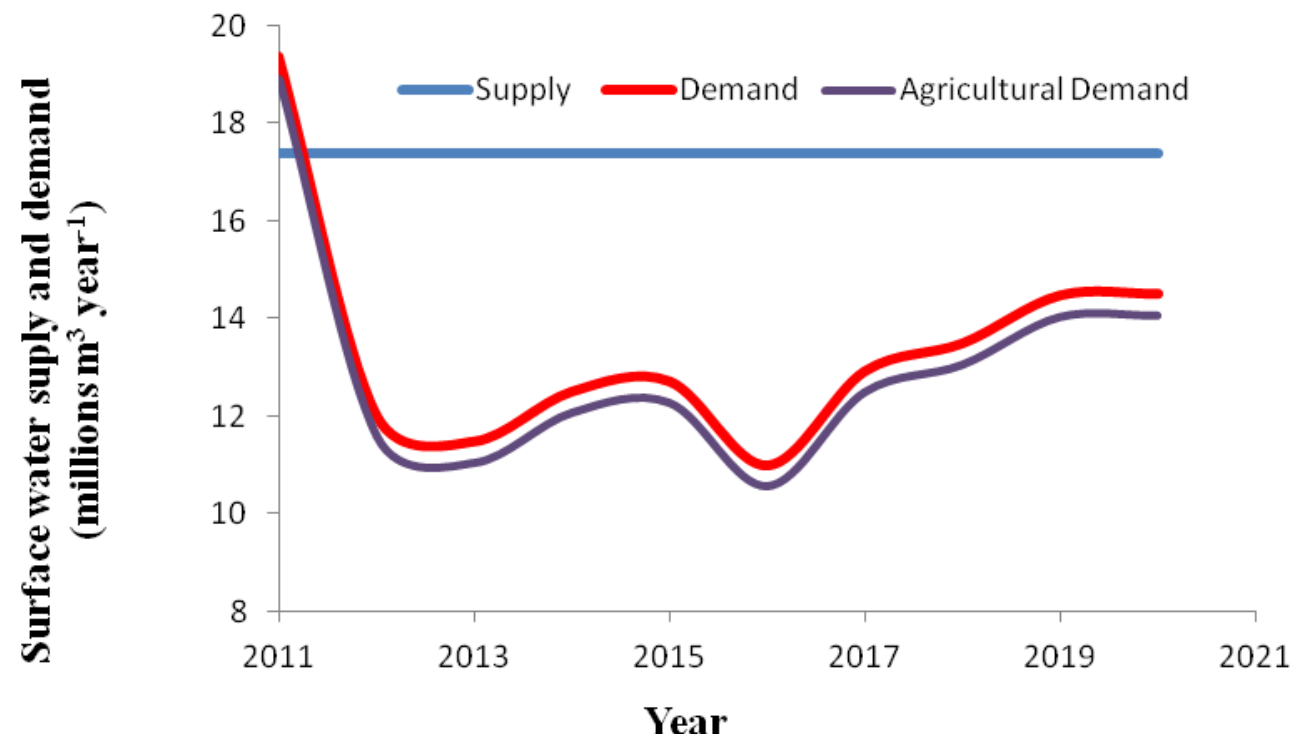

Additionally, the demand varies according to year, which may be explained by the precipitation volume that falls on the sub-basin area. Indeed, the historical data series shows that precipitation volume changes from year to year. While demand for irrigation water is decreased or non-existent in years of heavier rain, it rises in years of low precipitation.

In spite of being below supply for almost the entire period, the demand requires $77 \%$ of the water supply on average. This is what allows DAEE to classify the sub-basin condition as critical according to law.

Global SI and surface water SI under this scenario are shown in Figure 14. 
Figure 14. Global SI and Surface Water SI

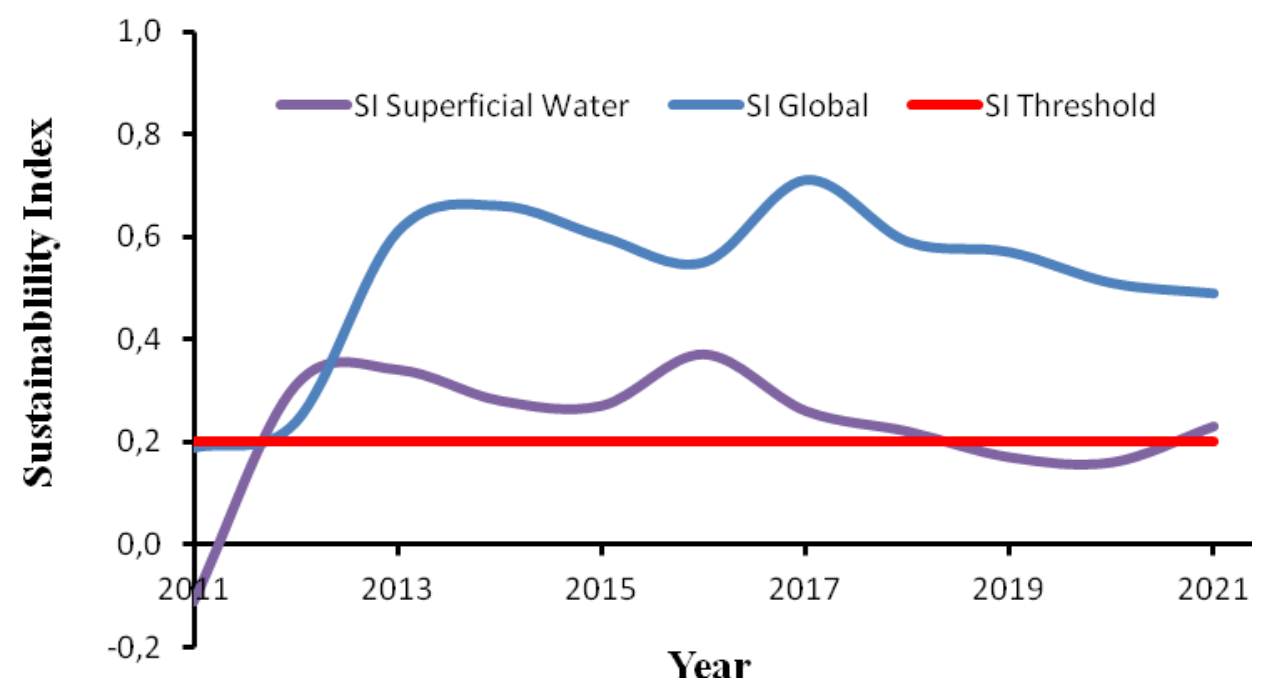

The Global SI in 2011 is 0.2 , the minimum value acceptable, but increases through the remainder of the period. The highest overall SI (0.71), observed in 2017, reflects no water supply stress in the Boi Branco sub-basin, as the demand is below the potential water supply of this water source.

However, the analysis of the surface water SI shows that it is well below 0.2 in the first year, but exceeds this reference value between 2012 and 2018, indicating the influence of precipitation on sustainability. Nonetheless, between 2019 and 2020, the SI value is once again below 0.2, and finally increases and remains a little above 0.2 in 2021. In the years where SI values are under 0.2 , a vulnerable condition is expected, suggesting that water the demand is higher than $80 \%$ of the supply. On the other hand, in the years where SI values exceed 0.2 , it seems that water supply stress is low or non-existent as the demand is lower than or equal to $80 \%$ of the potential water supply in the Boi Branco subbasin.

\section{Conclusions}

The results obtained using the proposed model are satisfactory, showing that the model mechanics are adequate.

In the simulation relating precipitation probability with the irrigation system efficiency, the best results observed, were those using a 50\% probability and irrigation efficiency equal to or greater than $80 \%$, followed by $75 \%$ probability and $90 \%$ irrigation efficiency. This indicates that good efficiency management allows using less water for irrigation while preserving the agroecological system.

Precipitation probability at $50 \%$ associated with an environmental flow of $1 / 40$ of the mean pluriannual flow promotes a decrease in the water demand, and thus contributes to sustainability in the sub-basin area. 
Considering only the surface water supply, irrigated agriculture can affect the sustainability of the Boi Branco sub-basin water resources under all scenarios. Therefore, appropriate measures have to be taken.

The sustainability of the Boi Branco sub-basin water resources may be possible if agriculturists start to exploit groundwater and surface water rationally, and improve the efficiency of irrigation systems.

\section{Acknowledgments}

To Coordenação de Aperfeiçoamento de Pessoal de Nível Superior (CAPES) for the scholarship and grant CAPES/PVE/CsF \# 063/2012.

\section{References}

Apple Maps. 2013. Satellite image. Available at: <https://www.apple.com/br/ios/ maps/>. Access on November 10th 2013.

Banco Mundial [World Bank]. Relatório sobre desenvolvimento mundial de 2010: desenvolvimento e mudança climática. [World Development Report 2010: Development and Climate Change]. São Paulo. Ed. UNESP, 2010. p. 133.

Brasil. Sistema integrado de gerenciamento de recursos hídricos do estado de São Paulo (SigRH). Regionalização Hidrológica [Integrated management of water resources in the state of São Paulo (SIGRH)]. Hydrologic regionalization. Available at: 〈http://www.sigrh.sp.gov.br/cgi-bin/regnet.exe/calcgeo\#r >. Access on January 4th 2013.

Bernardo, S., Soares, A. A. and Mantovani, E. C. Manual de irrigação [Irrigation Manual]. 8. ed. Viçosa, MG: Ed. UFV, 2006. p. 9-11.

CBH-ALPA. Plano de Bacia do Comitê da Bacia Hidrográfica do Alto Paranapanema para o período de 2012/2015 [Basin plan: Alto Paranapanema Basin Committee - 2012/2015], Piraju, SP, 15 dezembro de 2011. Available at: <http://www.comitealpa.com/pdf/planodebaciacbhalpa.pdf $>$. Access on August 4th 2013.

Goulart Junior, R. et al. Estudo da disponibilidade hídrica das bacias PCJ utilizando dinâmica de Sistemas [Study of water availability of the PCJ basins using system dynamics]. In: ENCONTRO NACIONAL DA ECOECO, IX, 2011, Brasília. Políticas públicas e a perspectiva da economia ecológica. Available at: <http://www.ecoeco.org.br/conteudo/publicacoes/encontros/ix_en/GT2-250-192 20110620183522.pdf>. Access on January 15th 2014.

ISEE SISTEMS. Stella 9.3. 2008. Programa de simulação [Simulation program]. Available in: <http://www.iseesystems.com/softwares/Education/StellaSoftware. aspx>. Access in March 3th 2012.

LEI 9.034, DE 27 DE DEZEMBRO DE 1994. Legislação estadual de Recursos Hídricos [Water Resources State Law]. Available at: 〈http://www.daee.sp.gov.br/ legislacao/Apdfestadual/LEI9034.pdf>. Access on January 6th 2014.

Mendoza, C. J. C. And Frizzone, J. A. Economia de energia em irrigação por pivô central em função da melhoria na uniformidade da distribuição de água [Energy saving in center pivot irrigation due to the improvement in water distribution uniformity]. Revista Brasileira de Agricultura Irrigada, Fortaleza, v. 6, n. 3, p. 
184-197, out. 2012. Available at: <http://www.inovagri.org.br/revista/index.php/ rbai/article/view/121/pdf_107. Access on February 3th 2014.

Nazemi, A., and Wheather, H. S. On inclusion of water resource managemente in Eargh system models - Part 2: Representation of water supply and allocation and oportunities for improved modeling. Eargh Syst. Sci, n. 19, p. 19-33, 2015a.

Nazemi, A. and Wheather, H. S. On inclusion of water resource managemente in Eargh system models - Part 1: Problem definition and representation of water demand. Eargh Syst. Sci, n. 19, p. 63-90, 2015 b.

ONU. UN-water anual report 2012. Available at: <http://www.unwater.org/ fileadmin/user_upload/unwater_new/docs/UN-Water_Annual_Report_2012.pdf>. Access on January 23th, 2014.

Orellana González, A. M. G. Sustentabilidad de los recursos hídricos en São Miguel do Anta, Minas Gerais: un enfoque de dinámica de sistemas [Sustainability of Water resources sustainability at São Miguel do Anta, Minas Gerais: a systems dynamics approach]. 2006. f.104. Dissertação (Mestrado em Economia Aplicada) - Universidade Federal de Viçosa, 2006.

Reichardt, K. A água na produção agrícola [Water in agricultural production]. São Paulo: Mc-Graw-Hill, 1978.119 p.

Sánchez-Román, R. M., Folegatti, M. V. and Orellana González, A. M. G. Situação dos recursos hídricos nas bacias hidrográficas dos rios Piracicaba, Capivari e Jundiai utilizando modelo desenvolvido em dinâmica de sistemas. [Water resources situation at Piracicaba, Capivari and Jundiaí river basins using a model developed in dynamic systems]. Engenharia Agrícola, Jaboticabal, v. 29, n. 4, p. 578-590, out./dez, 2009. Available at: <http://www.scielo.br/pdf/eagri/v29n4/ v29n4a8.pdf $>$. Access on February 6th 2014.

Schewe, J.; Heinke, J.; Gerten, D., Haddeland, I., Arnell, N. W., Clark, D. R., Dankers, R., Eisner, S., Fekete, B. M., Colon-Gonzalez, F. J., Gosling, S. N., Kim, H., Liu, X., Masaki, Y., Portmann, F. T., Satoh, Y., Stacke, T., Tang, Q., Wada, Y., Wisser, D., Albrecht, T., Frieler, K., Piontek, F., Warszawski, L. and Kabat, P. Multimodel assessment of water scarcity under climate change. Proceedings of the National Academy of Sciences of the United States of America, v. 11, n. 9, p. 3245-3250, 2014.

Souchon, Y. and Keith, P. Freshwater fish habit: Science, management and conservation in France. Aquatic Ecosystem Health and Management Society, Philadelphia, v.4, n.4, p.401-412, 2001.

Yoshikawa, S., Cho, J., Hanasaki, H. G. and Kanae, S. An assessment of global net irrigation water requirements from various water supply sources to sustain irrigation: Rivers and reservoirs (1960-2050). Hydrology and Earth System Sciences, v. 18, n. 10, p. 4289-4310, 2014.

$\mathrm{Xu}, \mathrm{Z}$. X., Jinno, K., Kawamura, A., Takesaki, S. and Ito, K. Sustainability analysis for yellow river water resources using the system dynamics approach. Water Resources Management, Netherlands, n. 16, p. 239-261, 2002. 
